DOI: $10.36695 / 2219-5521.2 .2020 .02$

УДК: 340.1

\title{
Н.M. ОНІЩЕНКО
}

Наталія Миколаївна Оніщенко, доктор юридичних наук, профресор, заслужений юрист України, академік НАПрН України, завідувач відділу Інституту держави і права імені В.М. Корецького НАН України*

ORCID: 0000-0002-1671-2139

\section{СОЦІАЛЬНИЙ ВИМІР СУЧАСНИХ ПРАВОВИХ РЕАЛІЙ}

Постановка проблеми. Зрозуміло, що сучасна життєдіяльнісна реальність, спровоковані пандемією багато негативних процесів не могли не торкнутися правової площини.

Відтак хочемо зауважити: здобутий досвід свідчить, що функціонування правової системи в «штатному режимі» і в екстремальних умовах мають, що зрозуміло, суттєві відмінності: в тому числі, а, можливо, і в першу чергу - щодо захисту прав, свобод та законних інтересів людини.

$\mathcal{\complement}$ аксіоматичним, і це знайшло своє підтвердження на практиці, що визначальну «стурбованість» викликають саме соціальні права людини. Декілька зауважень не стільки хрестоматійно-підручникового гатунку щодо розвитку цих прав, скільки щодо сегментів, які свідчать про необхідну сьогодні актуалізацію їх забезпечення та охорони.

Крім того, розгляд соціальних прав, їх «спроможностей» та гарантій повинен стосуватися тих загроз і викликів, що, на жаль, запропоновані новими реаліями сучасного життя.

Аналіз останніх досліджень. У цьому контексті можна наголосити, що проблематика соціальних прав людини знаходиться в центрі уваги багатьох сучасних дослідників. Так, цією темою в різні часи опікувалися О. Андрійко, Ю. Бисага, О. Петришин, В. Погорілко, О. Скрипнюк, Ю. Шемшученко. Різні аспекти заданої проблеми розглядались також М. Булкат, О. Данич, Р. Луцьким, О. Львовою, В. Січевлюком тощо. Втім, багато важливих питань обраного розгляду залишились, на жаль, поза увагою наукової спільноти, зокрема: питання критеріїв загальної соціальної ефективності; відповідності соціальних прав соціальним обов'язкам та соціальній відповідальності; значущості категорії «достатній життєвий рівень» у контексті розвитку соціальних прав тощо.

Формування мети статті. Мета даної статті полягає в тому, щоб підкреслити значущість ефективності забезпечення охорони та захисту соціальних прав людини в умовах сьогодення.

Виклад основного матеріалу. Декілька міркувань теоретичного формату. Так, на наш погляд, враховуватися повинні насамперед критерії загальної соціальної ефективності. Тобто критерії ефективності або індекси ефективності, як-то: ознаки межі, сторони, вияви, прояви певної діяльності, за допомогою аналізу яких можна визначити рівень і якість процесу, його відповідність потребам та інтересам громадянського суспільства і людини.

Такі критерії, з одного боку, об'єктивно пов'язані з потребами, інтересами та цілями суспільного розвитку (як загальнонаціонального, так і регіонального), а з іншого - дають можливість бачити (і вимірювати) задоволення (здійснення, реалізацію) назрілих потреб, інтересів і цілей кожного члена суспільства.

У сучасній Україні, в період формування правових основ державного і суспільного життя, гостро постає проблема ефективності законодавства. Недоліки його насамперед пов'язані з механізмом реалізації, відсутністю необхідних інституціональних форм. Крім того, недостатньо опрацьовані правові форми нормативного матеріалу (незбалансованості прав і обов'язків, незабезпеченості норм належними санкціями, невідповідності системи права та законодавства тощо).

Слід враховувати й те, що якість законодавства визначається і соціальним змістом, його відповідністю суспільним потребам та інтересам.

(C) Н.М. Оніщенко, 2020

* Nataliia Onishchenko, Dr. hab. in Law, Professor, Honored Lawyer of Ukraine, Academician of the National Academy of Pedagogical Sciences of Ukraine, Head of the department of V.M. Koretsky Institute of State and Law of the NAS of Ukraine 


\section{Видатні правознавці України}

Отже, розмірковуючи про соціальні права, наукова і громадянська спільноти повинні належним чином наголосити на тому, що в наш час не тільки держава виявилася неспроможною хоча б наближено до європейських взірців реагувати на відповідні загрози, а й, власне, національна правова система продемонструвала «аритмічний» характер функціонування в умовах сьогодення.

Національна правова система - це своєрідний показник сталого (або наближеного до нього) економічного, правового, політичного, соціального розвиту кожної держави, а головне - досягнутого рівня захисту прав, свобод та законних інтересів людини. Отже, цілком зрозуміло, що правова система, як втілення відповідного досягнутого рівня розвитку права, повинна бути здатною: а) до виконання певних завдань; б) відтворення необхідних функцій як при звичайному перебігу життя, так і за екстремальних умов.

Декілька слів про це детальніше. Сьогодні зростає соціальна спрямованість правової системи як засобу формування і реалізації інтересів суб'єктів шляхом закріплення певних цілей, норм, правил поведінки. Особливого значення при цьому набуває забезпечення оптимального поєднання соціального і правового принципів розвитку суспільства. Ця задача достатньо складна: правовий і соціальні принципи покликані забезпечити благо індивіда, сьогодні це першочергово - соціальні права. Як уже зазначалося, під соціальною політикою, що здійснюється державою, не можна розуміти тільки захист соціально незахищених верств населення. Це і спрямування на забезпечення ефективності соціальної результативності економічних перетворень, забезпечення соціальної складової правореалізаційної, інвестиційної, фінансової, податкової тощо політики держави.

Правова система соціальної, правової держави покликана забезпечити встановлену соціальною політикою стабільність громадянської згоди шляхом проголошення, реалізації і охорони соціально-правових умов для стимулювання активної частини населення на продуктивну працю як основу особистого добробуту; підтримання оптимального співвідношення між прибутками працездатної частини суспільства та непрацездатними громадянами; надання субсидій, відповідних пільг, скорочення та обмеження масштабів зубожіння; стримування безробіття, і як перспектива - забезпечення достатнього життєвого рівня.

І це щодо «штатного» перебігу подій. Втім, сьогодні це ще й такі загальносоціальні завдання, як гарантування національної безпеки, ліквідація наслідків пандемії, екологічних катастроф, реалізація соціальних програм, які відображатимуть позиції «все необхідне враховане», підтримання реабілітаційних заходів 1 .

Надзвичайно важливо в цих умовах, який «зріз» соціальних прав належить сьогодні забезпечувати правової системі, гарантувати державі та відстоювати судовій системі: ті, що будуть вибудовуватися тепер десятиліттями за залишковим принципом, чи, дійсно, ті, що допоможуть у сучасних українських реаліях жити не тільки «хлібом єдиним», а й мати достатні умови для самореалізації особи, захисту іiі честі та гідності.

Так, у європейських державах в умовах сьогодення право на достатній життєвий рівень $є$ одним із найголовніших соціальних прав особи. Незважаючи на те, що кожна людина повинна особисто дбати про свій добробут, їй, однак, мають бути створені умови для того, щоб вона мала можливість забезпечити собі мінімальний життєвий рівень. Особливо, коли йдеться про людину похилого віку, інваліда.

Це обов'язок держави, згідно з яким вона визнає право кожного на достатній життєвий рівень для нього самого та його родини ${ }^{2}$.

Слід зазначити, що поняття, дефініція «достатній життєвий рівень» не визначено у науковому обігу. Тому воно є оцінювальним; тобто, кожна людина сама для себе визначає рівень, який відповідає їі уявленням про достатній рівень життя. Проте сформульоване юристами Стародавнього Риму положення, відповідно до якого «право може і повинно бути визначеним» (Дигести Юстініана), є актуальним для будь-якої правової системи. Принцип визначеності, точності, однозначності правової норми вважається гарантією міцного правопорядку, оскільки за умови, що кожному члену суспільства зрозумілі його права й обов'язки, він одержує певну свободу дій і рішень у межах правового простору.

Отже, певна невизначеність існує в положеннях міжнародних документів, у яких йдеться про «достатній життєвий рівень». Справа ж держави визначити і встановити мінімальні стандарти, нижче яких життєвий рівень громадян знижуватися не може. Звичайно, забезпечення достатнього життєвого рівня становить складну проблему навіть для заможних держав.

Реалізація права на достатній рівень життя, безумовно, торкається внутрішніх ресурсів та можливостей держави. Право на достатній життєвий рівень включає, як уже йшлося, ще й такі можливості, як право на достатнє харчування, право на достатню кількість одягу, житло, на поліпшення умов життя. Правом на достатнє харчування є: свобода від голодомору; право на якісне харчування; можливість мати кошти для отримання якісного харчування тощо.

У міжнародному пакті про економічні, соціальні та культурні права визначено найбільш загальні програми, спрямовані проти голодомору.

Використовуючи право на працю, людина повинна отримувати необхідні їй кошти, щоб існувати. Забезпечити їй відповідні для цього умови - завдання внутрішнього законодавства кожної держави, так само як $\mathrm{i}$ встановлення необхідних стандартів якості харчування.

У зазначеному контексті слід звернути увагу на той факт, що питання охорони здоров'я в Свропі $€$ проблемою архіважливою, як і в усьому світі, особливо в умовах сьогодення. Нормативно це зафіксовано у ст. 35 Хартії Європейського Союзу про основні права 2000 р. Саме реалізація права на охорону здоров'я найбільше відображає неадекватність правової системи України, і не тільки щодо принципів соціальної, правової держави.

На жаль, досі зберігаються істотні відмінності в рівні медичного обслуговування різних соціальних прошарків і навіть окремих регіонів СС. Зокрема, системи охорони здоров’я країн Центральної та Східної Європи суттєво поступаються системам «старих» членів СС. 
Однак національні правові системи щодо регулювання охорони здоров’я скрізь характеризуються серйозним навантаженням. Насамперед йдеться про частку витрат на охорону здоров'я в бюджетах. Вже сьогодні це найбільша стаття витрат, але обсяг коштів, що виділяються на ці цілі, продовжує щорічно збільшуватися. За останні 30 років часта витрат на охорону здоров'я у ВВП зросла в усіх країнах ЄС. Наприклад, в Італії - 3 5,7 до 7,4 відсотка, в Іспанії - 3 5,6 до 7,3 відсотка.

Інший фактор, що ускладнює роботу національних систем охорони здоров'я, це демографічні тенденціï. Свропа старіє, вже у 2020 р. людей старше 75 стало на 40 відсотків більше ніж у 1990-і рр. Саме ці фактори, «недоопрацьовані» загальноєвропейською спільнотою, призвели в тому числі до поширення і розповсюдження COVID-19.

Висновки. Насамкінець зазначимо, що метою соціальної політики є забезпечення матеріальних благ громадян, досягнення стабільності та безпеки життя в суспільстві, цілісності та динамізму його розвитку.

Відомо, що в суспільстві зберігаються спокій та стабільність, коли кількість незадоволених чи незгодних 3 проведенням державної політики становить не більше 20 відсотків населення. Тому вкрай важливо для забезпечення соціальних прав, як зазначають провідні юристи-практики та представники наукового осередку, опрацювати наступні напрями:

1. Наукове прогнозування розвитку права, законодавства, економіки, зростання населення, створення нових галузей виробництва та робочих місць; розробка відповідних планів прогнозів та матеріально-фінансової підтримки в економіці, соціальній сфері, боротьба з недобросовісною конкуренцією, монополізмом в економіці тощо.

2. Перерозподіл матеріальних благ між регіонами та прошарками населення, спрямування їх на забезпечення досягнутого даною країною середнього рівня життя на всій території країни, недопущення бідності, зміни якості показників життя в бік погіршення.

3. Створення державних, насамперед правових, гарантій для запобігання стихійним лихам, епідеміям, епізоотіям, техногенним катастрофам, для негайної ліквідації їх наслідків, допомога потерпілому населенню.

4. Створення доступних для широких прошарків населення систем освіти, охорони здоров'я, пенсійного забезпечення, вирішення інших соціальних питань, з урахуванням питання безпеки громадян, певних соціумів, груп населення тощо.

Крім того, проведення «добротної» соціальної політики неможливе сьогодні без наступних констатацій: важливо наголосити, що для забезпечення на практиці соціальних прав людини необхідно доктринально опрацювати і зреалізувати категорію «соціальні обов’язки», в тому числі соціальну відповідальність: держави, бізнесу, кожного члена громадянського суспільства. Без належних, кореспондуючих правам обов'язків ставити питання про належні соціальні права неможливо ні в теоретичному сенсі, ні в практичній площині.

${ }^{1}$ Копиленко О.Л., Оніщенко Н.М. Забезпечення прав людини в контексті радіаційного захисту: передумови практичної реалізації. Бюлетень Мін'юсту Украӥни. 2020. № 1. С. 34-40.

${ }^{2}$ Міжнародний пакт про економічні, соціальні і культурні права. URL: https://zakon.rada.gov.ua/laws/show/995_042

\section{Резюме}

Оніщенко Н.М. Соціальний вимір сучасних правових реалій.

Стаття присвячена критеріям ефективності охорони та захисту соціальних прав людини. Окремо наголошено на необхідності врахування умов, коли національні правові системи «працюють у нештатному режимі», зокрема, світової пандемії, агресії РФ, економічні дестабілізації. Увага присвячена також врахуванню при розгляді соціальних прав - соціальних обов’язків та соціальної відповідальності.

Ключові слова: соціальні права, критерії соціальної ефективності, соціальні обов'язки,соціальна відповідальність, соціальна політика.

\section{Резюме}

Онищенко Н.Н. Социальное измерение современных правовых реалий.

Статья посвящена критериям эффективности охраны и защиты социальных прав человека. Отдельно отмечена необходимость учета условий, когда национальные правовые системы «работают в нештатном режиме», в частности, мировой пандемии, агрессии РФ, экономические дестабилизации. Внимание уделено также учету при рассмотрении социальных прав социальных обязанностей и социальной ответственности.

Ключевые слова: общественные права, критериальная социальная эффективность, социальные обязанности, социальная ответственность, социальная политика.

\section{Summary}

Nataliia Onishchenko. The social dimension of the modern legal realities.

We would like to note that the experience gained shows that the functioning of the legal system in the "regular mode" and in extreme conditions have, of course, significant differences: including, and perhaps primarily in the protection of rights, freedoms and legitimate interests man.

It is axiomatic, and this has been confirmed in practice, that it is social human rights that are the defining "concern". A few remarks are not so much a textbook textbook on the development of these rights, but on the segments that indicate the need for today's actualization of their provision and protection.

Finally: the purpose of social policy is to ensure the material well-being of citizens, to achieve stability and security of life in society, the integrity and dynamism of its development. 
It is known that society remains calm and stable, when the number of dissatisfied or disagree with public policy is not more than twenty percent of the population.

In addition, the implementation of "sound" social policy is impossible today without the following statements: it is important to emphasize that to ensure the practice of social human rights it is necessary to doctrinally develop and implement the category (social responsibilities) including social responsibility: state, business, each member civil society. Without proper, corresponding rights to raise the question of proper social rights, it is neither possible in the theoretical sense nor in the practical sense.

Key words: social rights, social efficiency criteria, social obligations, social security, social policy.

DOI: 10.36695/2219-5521.2.2020.03

УДК 340.13

\section{Н.М. ПАРХОМЕНКО, Т.С. ПОДОРОЖНА}

Наталія Миколаївна Пархоменко, доктор юридичних наук, профресор, вчений секретар Iнституту держави і права імені В.М. Корецького НАН України* ORCID: 0000-0002-5870-9261

Тетяна Станіславівна Подорожна, доктор юридичних наук, доцент, профресор юридичного факультету Львівського торгівельно-економічного університету**

ORCID: 0000-0003-0502-950X

\section{ПРАВОВА РЕФОРМА ЯК ІНСТРУМЕНТ КОНСТИТУЦІОНАЛІЗАЦІї ПРАВОВОГО ПОРЯДКУ}

Державно-правовий механізм забезпечення правового порядку являє собою систему державних та недержавних інституцій і правових засобів, що здійснюють результативний вплив на соціальні відносини i процеси, які зазнають загроз, з метою захисту життєво важливих інтересів суспільства і держави. Механізм забезпечення правопорядку завжди перебуває в динаміці ${ }^{1}$. Відповідно, процес конституціоналізації правового порядку в умовах постійних економічних, політичних і соціальних змін може бути успішним лише у разі здійснення державою послідовної, науково обгрунтованої і внутрішньо несуперечливої правової політики, яка орієнтована на досягнення таких правових цілей, які є значущими для людини, їі основних прав і свобод. Відповідно, така людиноцентристська політика здатна забезпечити правовий порядок лише на основі стратегічного підходу. Виступаючи найоптимальнішим засобом досягнення рівноваги у правовій системі, правові стратегії усувають протиріччя, які виникають у сучасному праві. Крім того, зміст правових стратегій дає змогу оцінити стан прав людини або проаналізувати зміни, які відбуваються в судовій системі. Вони дають орієнтири, необхідні для досягнення балансу приватних і публічних інтересів, усунення протиріч між чинним правом і юридичною практикою, правом і правосвідомістю. Отож, правова стратегія стає основою державно-правового регулювання суспільних відносин і, як наслідок, вважається основним джерелом правового порядку.

Реалізація стратегічного підходу в процесі конституціоналізації правового порядку може бути найбільш успішною за умови, що планування повинно охоплювати не модернізацію державного механізму в цілому, а саме окремих функціонально відокремлених його підсистем. Тому важливо зазначити, що на стан правопорядку, крім традиційно значущих чинників, особливо впливають процеси реформування державності та відповідних соціально-економічних структур. Саме в наявному правопорядку практично проявляється не тільки якість правових суспільних інститутів, а й реальна правова політика держави, яка є основою правового прогресу в Україні.

Сьогодні українське суспільство всерйоз стурбоване станом правового порядку в країні. Незважаючи на всі зусилля держави, поки що не вдалося істотно зупинити зростання злочинності, забезпечити в повному обсязі дотримання прав та свобод людини і громадянина 2 . Так, аналіз основних тенденцій щодо порушень прав людини в Україні протягом останніх років свідчить, що основні зусилля держави витрачаються на військовий конфлікт і боротьбу з корупцією, а права людини натомість потерпають. Тобто істотно нівелюється дія одного з основоположних критеріїв правового прогресу - його ціннісна основа, що, в свою чергу, впливає на рівень його ефективності. Крім того, такий стан справ обумовлює відхилення від стратегічного спрямування реформ, а отже, і від кінцевої їх мети. Можливо, однією з причин цього є недосконалість самих реформаторських пропозицій. На наш погляд, удосконалення потребує система законодавства, і лише після цього реформування інших елементів правової системи. Закономірно в цьому зв’язку, що курс на встановлення

(C) Н.М. Пархоменко, Т.С. Подорожна, 2020

* Nataliia Parkhomenko, Dr. hab. in Law, Professor, Scientific Secretary of V.M. Koretsky Institute of State and Law of the NAS of Ukraine

** Tetiana Podorozhna, Dr. hab. in Law, Associate Professor, Professor of Lviv University of Trade and Economics 